\title{
IMMUNE-MEDIATED NECROTIZING MYOPATHY ANDSYSTEMIC LUPUS ERYTHEMATOSUS AS OVERLAP SYNDROME: A CASE REPORT
}

Karina Fernanda Pucha Aguinsaca1,^, Thiago Quadrante Freitas ${ }^{1}$, João Calvino Soares de Oliveira ${ }^{1}$, Mateus Cavarzan Lopes ${ }^{1}$, André Silva Franco ${ }^{1}$, Isabele Parente de Brito Antonelli ${ }^{1}$, Guilherme Guimarães Moreira Balbi ${ }^{1}$, Leonardo Flavio Guerrón Olalla ${ }^{1}$, Henrique Ayres Mayrink Giardini¹, Michelle Ugolini Remião Lopes ${ }^{1}$, Samuel Katsuyuki Shinjo ${ }^{1}$

1.Universidade de São Paulo, São Paulo (SP), Brazil.

*Corresponding author: karyp86@hotmail.com

\section{BACKGROUND}

Myalgia, muscle tenderness, or muscle weakness can occur in systemic lupus erythematosus (SLE). However, myositis and severe muscle weakness are relatively uncommon in SLE. Herein, we report a patient with well-defined immune-mediated necrotizing myopathy (IMNM) and new-onset SLE.

\section{CASE REPORT}

A 21-year-old white woman presented with a 4-month history of muscle pain, and symmetric, progressive and mainly proximal weakness of four limbs. Moreover, the patient had malar rash, polyarthritis, and a 7-kg weight loss in the same period. The patient was admitted in our center with objective limb muscle weakness with 3/5 proximal limb muscle degree strength, according to the Medical Research Council, and serum levels of creatine phosphokinase of $7844 \mathrm{U} / \mathrm{L}$. Muscle biopsy revealed sparse necrosis without inflammatory cell-infiltration, and moderate MHC-I staining. In addition, laboratory data showed antinuclear antibodies with 1/320 nuclear fine speckled and cytoplasmic dense fine speckled patterns, positive anti-Ro-52, anti-Sm and anti-ribosomal P antibodies, hypocomplementemia (C3 $51 \mathrm{mg} / \mathrm{dL}$ and C4 $8 \mathrm{mg} / \mathrm{dL}$ ), lymphopenia ( $250 \mathrm{cells} / \mathrm{mm}^{3}$ ), and subnephrotic proteinuria (protein-creatinine ratio $500 \mathrm{mg} / \mathrm{g}$ ) with urinary granular casts. Prednisone $1 \mathrm{mg} / \mathrm{kg} /$ day and azathioprine were initiated. However, due to severe muscle impairment and new-onset dysphagia, methylprednisolone pulse therapy $(3 \mathrm{~g})$ and intravenous immunoglobulin $(2 \mathrm{~g} / \mathrm{kg})$ were prescribed. Two weeks after, muscle strength improved (4/5 proximal limb muscle degree strength); there was no dysphagia; and the patient regained her weight. The serum levels of creatine phosphokinase decreased to $1073 \mathrm{U} / \mathrm{L}$, and all SLE laboratory parameters improved. Currently, the patient has been followed up in our outpatient clinic.

\section{CONCLUSION}

We report da well-defined IMNM in a patient with new-onset SLE. It is difficult to distinguish myositis in associated with SLE from SLE-related musculoskeletal involvement. Generally, true myositis, as the present case, differs in its clinical presentation, defining an overlapping syndrome. These cases may require aggressive immunosuppression, as illustrated in the present case report.

\section{KEYWORDS}

Immune-mediated, Necrotizing, Myopathy, SLE. 